\title{
Mobilising sociology of sport for social change beyond the pandemic ${ }^{1}$
}

\section{Movilizar la sociología del deporte para el cambio social más allá de la pandemia}

\author{
Ramón Spaaij ${ }^{a, b}$ \\ anstitute for Health and Sport, \\ Victoria University, Melbourne, Australia \\ bDepartment of Sociology, University of Amsterdam,
Amsterdam, The Netherlands \\ bDepartment of Sociology, University of Amsterdam,
Amsterdam, The Netherlands \\ Ramon.Spaaii@vu.edu.au
}

\section{Key words}

- Action research

- Inclusion

- Play

- Public sociology

- Social change

- sport for development

\begin{abstract}
Amid the Covid-19 pandemic, conversations about how to build sport back better are becoming increasingly pronounced. The crisis both deepens inequities and creates opportunity as a new way to configure sport post-pandemic demands to be discovered. The challenge has been thrown down to sociologists to help reimagine and reshape the course of sport. What might such re-enchantment look like? And how might it help realise the sociology of sport's untapped potential to advance impactful public sociology? This paper explores these questions with a particular focus on sociologists of sport as co-creators of, and actors in, social change. I discuss five issues that I see as being relevant for rethinking and reconfiguring sport beyond the pandemic: (1) reclaiming the ludic and pleasure; (2) rethinking sociality in sport; (3) social inequities and 'sport for all'; (4) de-/re-centring power in sport for development; and (5) global interdependence and interconnectedness. The insights presented can hopefully make a modest contribution to our collective understanding of transformative practice in and through the sociology of sport in uncertain times.
\end{abstract}

${ }^{1}$ This paper is an edited and fully revised transcript of a keynote address delivered at the European Association for Sociology of Sport (EASS) Annual Congress in September 2021. 


\section{Palabra clave}

- Investigación-acción

- Inclusión

- Juego

- Sociología pública

- Cambio social

- Deporte para el desarrollo

\section{Resumen}

En medio de la pandemia de la Covid-19, las conversaciones sobre cómo reconstruir mejor el deporte están cada vez más presentes. La crisis profundiza las desigualdades y crea oportunidades como una nueva forma de configurar las demandas deportivas pospandémicas por descubrir. En este context, se ha lanzado el desafío a los sociólogos de ayudar a reimaginar y remodelar el curso del deporte. ¿Cómo sería tal re-encantamiento? ¿Y cómo podría ayudar a comprender el potencial sin explotar de la sociología del deporte para promover una sociología pública impactante? Este artículo explora estas preguntas con un enfoque particular en los sociólogos del deporte, como co-creadores y actores del cambio social. En él afronto cinco temas que considero relevantes para repensar y reconfigurar el deporte más allá de la pandemia: (1) recuperar lo lúdico y el placer; (2) repensar la socialidad en el deporte; (3) desigualdades sociales y "deporte para todos"; (4) descentralizar /volver a centrar el poder en el deporte para el desarrollo; e (5) interdependencia e interconexión global. Es de esperar que las ideas presentadas puedan contribuir modestamente a nuestra comprensión colectiva de la práctica transformadora en y a través de la sociología del deporte en tiempos inciertos.

\section{Introduction}

Reflecting the contemporary debate on public sociology (Burawoy 2005; Clawson et al. 2007), sociologists of sport have been called 'off the bench' (Zirin 2008) in order to serve as active contributors to public discourse and, ultimately, to social change. Zirin $(2008,31)$ contends:

The athletic industrial complex keeps throwing pitch after juicy pitch down the middle of the plate. It's time for sports sociologists to get the bats off their shoulders and begin to shape debates within the sports world.

Fortunately, sociologists of sport do not have to go it alone. It is recognised that scholars do not work in a vacuum and that, without the assistance of 'organic intellectuals' (e.g. athletes, sport organisations, community groups) and the coalitions they can provide, their words will regularly fall on deaf ears (Bairner 2009). This type of partnership between scholars and people with lived experience and practical knowledge can enable sociologists of sport to effect change in ways that would not have been possible for academics alone (Bairner 2009).
Such contemplations gain particular significance amid the Covid-19 pandemic as conversations about how to build sport back better are becoming increasingly pronounced. The crisis both deepens inequities and creates opportunity as a new way to configure sport post-pandemic demands to be discovered. The challenge has been thrown down to sociologists to help reimagine and reshape the course of sport. For example, Pape and McLachlan (2020) invite sports scholars to mobilise their critical sociological imaginations to consider how sporting institutions could be configured differently postpandemic. As mythologist and storyteller Michael Meade (2020) reminds us, where a person, group or society feels most restricted, that is where the greatest lack of imagination will be found. Such imagination, infused by sociological theory and research, is sorely needed in the present moment. Indeed, if we - collectively - neglect to heed this call, Rowe's $(2020,710)$ grim prediction looms:

It is unlikely that sport after the pandemic will be transformed, but it will certainly be changed. If sociology does not play its part in helping to re-set the course of sport after the virus has been controlled, then it certainly will have lost the moral compass that first guided 
the discipline into the equally troubled waters of early modernity from which the institution of sport emerged.

How might these developments play out? What are some of the key implications and opportunities for the sociology of sport? Whilst much has been said about the present and future impact of the Covid-19 pandemic, much less is known. We simply do not know what the long-term impact of this pandemic will be. What we can do, is ask questions. So, inevitably, I offer more questions than answers, with the hope that these questions may contribute to wider, ongoing conversations through which sociological understandings of sport can inform policy, practice and public discourse. What I would like to do in this paper is to mobilise a sociological imagination, grounded in my own vantage point (which, inevitably, is partial and shaped by my own biography and professional interests), to succinctly discuss five issues that I see as being relevant for rethinking and reconfiguring sport beyond the pandemic. These five issues are: (1) reclaiming the ludic and pleasure; (2) rethinking sociality in sport; (3) social inequities and 'sport for all'; (4) de-/ re-centring power in sport for development; and (5) global interdependence and interconnectedness.

\section{Re-enchanting sport by reclaiming the ludic and pleasure}

Simone Fullagar (2020) writes:

The affective dimension of sport will require greater attention in research, policy and practice as the pandemic has intensified anxiety and range of emotions that are likely to have an ongoing impact in some form on participants, spectators, staff and volunteers.

I wholeheartedly agree with this suggestion. I propose that we pay close attention to ways in which sport can be re-enchanted, to borrow Max Weber's well-known terminology, whereby re-enchantment may be viewed as a key to understanding alternative social futures (Lee 2010). As part of this, I believe we need to reclaim and re-imagine both the ludic and affective dimensions of sport. One way to do so is by putting play at its heart. At a time when hyper-commercial elite sport is trying to rethink its business model, how can we create more space for the play element? Play is, by definition, creative and provides a foundation for imagination (Huizinga 1949). Gray (2013) argues that play allows participants to impart their own meaning on activities, rather than meaning being imparted (primarily) top down. Research has shown how sociality can be fostered in novel, even transformative, ways when competitive sports are re-shaped (or de-shaped) into games and less structured forms of play (e.g. Sterchele 2015; Koopmans and Doidge, in press).

With regard to the affective dimension of sport, I am drawn particularly to the radical and emancipatory potential of pleasure. Sociological interest in sporting pleasures has matured over the years, as documented in, for instance, the book sport and the Social Significance of Pleasure (Pringle, Rinehart, and Caudwell 2015). As this book reminds us, whilst experiencing pleasure may not result in structural transformation, some forms of pleasure are understood as acts of resistance through subjects' exercise of agency. Sporting pleasures are creative encouraging forces that underpin relationships, identities and lifestyles. I might add that, in foregrounding pleasure as an important part of the language and architecture of emotions and affect in sport, we should pay close attention to the pleasure of those most impacted by oppression or exclusion (Brown 2019), as it can reveal both wider power relations and possibilities for social and political transformation (e.g. Webster, in press).

\section{Rethinking sociality in sport in times of physi- cal distancing}

Bodily co-presence is a core feature of most sport activities (with the exception of esports). Sport conjures up images of sweaty bodies in close proximity. For contact sports such as martial arts, this includes high levels of physical contact between participants. The habitual of bodily co-presence and touch - other players, wiping sweat of our faces, adjusting our sports uniforms - has altered completely during the Covid-19 pandemic (cf. De Klerk 2020). How do patterns of physical distancing, or what the Dutch Prime Minister has termed the '1.5-metre society', affect how we engage in physical activity? How are connection and proximity in sport experienced and (re)imagined in and beyond the pandemic? Emerging evidence suggests that the effects will continue to be felt as the pandemic evolves and as participants navigate the challenges of returning to sport after shutdown and amid strict public health regulations. For example, Staley et al. $(2021,6)$ found that participants' perceived challenges to returning to sport participation post-shutdown 'coalesced around the competing ideas of staying safe while staying together'. 
The 'staying connected' experience of sport appears to have changed during the pandemic. Due to public health regulations, sport was increasingly experienced alone or in small groups in outdoor spaces, or else at home alone or with household members (Evans et al. 2020). Participation also became even more mediated through mobile apps, computer screens, tracking technology and other digital platforms. There are indications that the use of tracking technology, the rise of esports and online training sessions/courses could become even more prevalent in years to come. As Evans et al. (2020) rightly argue, it will be interesting to observe the extent to which the digitalisation - and, I would add, informalisation (Jeanes et al. 2019) - of sport that started well before the Covid-19 pandemic will continue to intensify. And how does this affect forms of sociality in and through sport? What are the new and established patterns of person-to-person interaction that emerge in these conditions?

In helping us to theoretically ground these questions, the microsociology of Randall Collins (2004, 2016) has much to offer (for applications to sport, see also Cottingham 2012; Spaaij and Schaillée 2021). For Collins, social and affective dynamics consist of chains of interaction rituals (IRS). These rituals are a mechanism of mutually focused emotion and attention producing a (momentarily) shared reality, which generates solidarity, symbols of group membership and moral norms. Collins' interaction ritual theory can inform our thinking about the interplay of online and face-to-face interactions in sport. Since online and offline processes are often intertwined, this raises the question how we understand and enact hybrid ritual chains in sport, and with what implications for sociality. In Collins' theory, successful rituals essentially involve bodily entrainment (i.e., synchronisation of attention, body language and talk), which is why he is sceptical about whether digital interactions can have sufficient intensity for generating strong symbols and solidarity. Although he recognises that future technological advances may enable intensification, Collins (2011) has argued that:

Up to now, the electronic media produce only weak IRs, because they lack most of the ingredients that make IRs successful: bodily presence is important because so many of the channels of micro-coordination happen bodiIy, in the quick interplay of voice rhythms and tones, emotional expressions, gestures, and more intense moments, bodily touch.

I would say that, at the present moment, this is still very much an empirical question that warrants further research and theorisation (see e.g. the discussion initiated by Tranow 2020). This is especially so given the rapid development of new technologies including Augmented Reality, Virtual Reality and other immersive technologies that create distinct experiences by merging the physical world with a digital or simulated reality. Such research has the potential to produce new insights into the social and affective dynamics of the digital and hybrid sportscape.

\section{Social inequities and 'sport for all'}

As a scholar of diversity and inclusion in sport, I have experienced first-hand some of the impacts the covid-19 pandemic has on existing and emerging inequalities. Unequal distribution of access to resources and facilities, coupled with various forms of exclusion and discrimination, were already key issues in the sociology of sport before the pandemic (e.g. Collins with Kay 2014; Spaaij, Magee, and Jeanes 2014). My previous studies showed that sport organisations often did not perceive diversity and inclusion to be part of their core business (e.g. Spaaij et al. 2014). So what happens now in a high-pressure environment with greater resource constraints? How can we avoid falling into a 'business as usual' mode that fails to adapt to a changing world (Fullagar 2020)? Will the base targeted by sport organisations narrow (i.e. predominantly white, middle class, able-bodied, heterosexual men) or widen? Who are the 'new normal' in sport, and whose voices and experiences are silenced? And, as Evans et al. (2020) rightly ask, will the Covid-19 pandemic result in the further exclusion or stigmatisation of marginalised groups?

Although it is too early to answer these questions confidently with the necessary empirical evidence, some early patterns are emerging. If we look beyond sport, it is clear that the pandemic has exacerbated global inequalities (Sen 2020). Low- and middle-income countries (LMIC) are among the worst affected by the pandemic due to structural vulnerabilities and their disadvantaged position in the global political economy (Bhattacharya and Islam 2020; Bhattacharya and Khan 2020). Joseph Stiglitz $(2020,19)$ predicts that 'the pandemic itself is likely to increase disparities, leaving long-lasting scars, unless there is a greater demonstration of global and national solidarity'. One example is the unequal access to and distribution of Covid-19 vaccines across high- and low-income countries, which further accentuates global inequality. Vaccine nationalism comes at a high economic and health cost for individuals in poorer countries (Hafner et al. 2020), and undermines the global solidarity that Stiglitz calls for. 
In sport, emerging patterns highlight the need for a critical and intersectional approach to social inequalities in participation. Anecdotally, in my conversations with residents and advocacy groups in Melbourne, Australia, low-income families from newly arrived migrant backgrounds expressed heightened concerns about access (e.g. cost, transport and facilities), social connectedness, gender equity and discrimination. During the Covid-19 pandemic, newly arrived young people and their families have been reporting high levels of social isolation and increased discrimination. The pandemic has exacerbated their already lower participation rates in sport and physical activity, with a likely impact on health and wellbeing. Girls and young women were particularly affected. Emerging evidence from other countries confirms this development. In the Netherlands, for example, social inequalities in sport participation increased during the pandemic (Grubben and Hoekman 2021). The level of participation among women from non-western migrant backgrounds decreased from 42\% in 2019 to $34 \%$ in 2020. Participants with low educational attainment also saw their physical activity levels decrease relative to those with average or high educational attainment (Grubben and Hoekman 2021). Based on these preliminary empirical insights, we might conclude that in order to emerge stronger from the pandemic, it is vital to actively address inequalities and strengthen opportunities in community sport in terms of gender equity and anti-racism.

The Covid-19 pandemic not only reproduces or reinforces existing inequalities, but it also activates new social and political cleavages that graft onto established inequities and divides. There appears to be a widening societal divide between those who are vaccinated and those who are not. Vaccination status has been emerging as a new fault line that increasingly demarcates in-groups and out-groups, and elicits strong 'us' versus 'them' feelings. It is becoming increasingly apparent that, in many countries, unvaccinated people will face more Covid-19 restrictions in the future which, at a societal level, may fuel polarisation and community resistance. The distinction between the vaccinated and unvaccinated - or those with or without Covid-19 vaccine passports - might contribute to the creation of a 'two-tier system' that intersects with existing global inequalities (Nuki et al. 2021). For example, there is scientific evidence of vaccine hesitancy among migrant groups in multiple countries, which may be exacerbated by xenophobia and racism (Tankwanchi et al. 2021). The introduction of the controversial $2 \mathrm{G}$ system in Austria may well be a sign of things to come. In the $2 \mathrm{G}$ system, people receive a QR code to enter public indoor spac- es like sports stadiums, museums and restaurants, if they have been fully vaccinated or have recently recovered from Covid-19. In contrast, people who are unvaccinated or do not have proof of a recent recovery are only allowed to leave their homes for work, to shop for essentials or for emergencies (Cohen 2021).

This social divide is already becoming visible in sport. Increasingly, only those with certification of Covid-19 immunisation, proof of recent recovery from Covid-19 or a recent negative test result are permitted to go to the gym, play sports and attend sports events. For example, the Australian Open has banned all unvaccinated players, staff and spectators from attending the event in 2022. This requirement leaves in doubt the status of the top-ranked men's tennis player, Novak Djokovic, who has refused to reveal his vaccination status (at the time of writing). We see this social divide across the recreational sports sector too. In the Australian state of Victoria, for instance, gyms are open only to those who are fully vaccinated, under 16 years of age, or have a valid medical exemption. People who do not meet the vaccination requirements are not permitted to enter.

I encourage scholars to mobilise sociological theories and concepts that can help us make sense of these new developments and their impacts across the sports world. At first sight, multiple sociological approaches that have proven valuable to the study of sport continue to be highly relevant for this purpose. To name but two, Foucault's work on discourse, biopower and regimes of truth seems particularly apt (e.g. Foucault 1974, 2008), as do Norbert Elias's concepts of figurations and established-outsider relations (e.g. Elias and Scotson 1965). Moreover, there might be space for theoretical innovation in seeking to understand how the new social divide intersects with established inequalities, for example through the use of intersectional approaches.

\section{De-/re-centring power in sport for development}

We can gain further insight into sport and global inequalities by examining how the sport for development (SfD) sector has been impacted by the pandemic. Preventative health measures were introduced, programs were suspended, downsized or moved online, and the global network exchanges and resources that many SfD organisations rely on (including funding) were disrupted. This raises questions as to how the pandemic will impact the SfD sector's transformative agendas and capability into the future. More specifically, how are power relations in SfD, such as donor-recipient relations (Spaaij, Oxford and Jeanes 
2016), affected? The latter is a key example of what Rowe (2020) calls the structural imbalance that the pandemic has mercilessly exposed. SfD is embedded within international development agendas and cooperation characterised by power relations and unequal resources (Giulianotti et al. 2016). With notable exceptions of local mobilisation and agenda-setting (e.g. Lindsey and Gratton 2012) and LMIC cooperation (e.g. Huish 2011), it is rather common for SfD programs delivered in LMICs to be heavily influenced by high-income countries' agendas, organisations, and funding, to the point where they may be considered donor biased or neo-colonial (Darnell 2012).

Empirical evidence regarding the impact of Covid-19 on inequalities and power relations in the SfD sector is still very limited, but there are some early indications. Lack of funding and challenges to engage the most vulnerable participants, for example through online program delivery, are frequently listed as key concerns. For example, the sport for Development Coalition (2020) found that the pandemic has had a 'significant impact on organizations in the [SfD] sector, from reduced funding and financial security, to a forced reduction and adaptation in delivery, and increased challenges in engaging participants'. The report concludes that organisations are left feeling vulnerable and uncertain of their futures, and of their ability to serve the most vulnerable members of society. It calls for resources to be made available to SfD organisations to continue providing the support so vital at this time, a call that is echoed by Donnelly et al.'s (2020) discussion paper for the Commonwealth Secretariat, which similarly urges governments, the private sector and civil society to invest in SfD. Beyond financial resources, we have also seen the creation of various practical resources and guides that have been made freely available to SfD organisations around the world. For example, Common Goal, streetfootballworld, Kick4Life, and the Sport for Good Response Fund developed a tool to support SfD organisations through a 'structured process designed to help them move from survival mode to diverse and robust longterm financial sustainability' (Fleming 2020).

As noted earlier, much has been made of the sports world's adaptability to the 'new normal'. Herein lies an opportunity to 'build back better' (DonnelIy et al. 2020), and to reimagine and recalibrate the course of sport (Rowe 2020), including how the SfD sector's governance, impact and sustainability may be enhanced. To date, these conversations have focused largely on the short term and the micro level: how to resolve the current challenges in delivery, including (digital) innovations to adapt to the current circumstances. In the midst of the Covid-19 pandem- ic, this concern with immediate needs understandably overshadows bigger-picture questions regarding power relations and autonomy in SfD. Yet, given what we know about the ongoing exacerbation of global inequalities, there is also an opportunity to develop new ways of thinking and action around these very questions. More attention should be afforded to how future work can better facilitate shared ownership of SfD efforts (Burnett 2015), as well as to ways to reconfigure the relationships between donors, SfD organisations and local communities.

\section{Global interdependence and interconnectedness}

Debates on scale, and especially globalisation, are a key staple of modern and late modern sociology. How might the pandemic affect ongoing processes of time-space compression? For example, how might the organisational structure and lived experience of sport change in response to the pandemic? I see at least two fruitful avenues for future research in this regard.

First, we may need to rethink notions of the 'glocal' and 'community' in sport due to a potential re-localisation or re-territorialisation of sport and leisure experiences. In places that have experienced strict lockdowns, including curfews and closure of sports facilities, participation in sport and exercise was largely restricted to local parks, backyards, beaches, garages and virtual training sessions or workouts. Most of this participation was informal and self-organised in nature, rather than club- or program-based.

unsurprisingly, the nature of play was also influenced by the pandemic, constraining movement but also stimulating creativity and innovation. I recall how, during lockdowns, children in my neighbourhood invented multiple virus-related games. They played games such as 'coronaball', a game adapted from dodgeball that involves dodging a spiky plastic ball that loosely resembles illustrations of the virus (Cray 2020). They also played 'coronavirus tag', where they would tag someone by touching them and hence 'infecting' them with Covid-19. They invented other games that were not directly inspired by Covid-19, but shaped by the restrictions. During the lockdown rules that allowed residents only to travel within a $5 \mathrm{~km}$ radius from their home to go shopping and exercise (with a few exemptions), children and adults alike found new ways to enjoy the outdoors in the vicinity of their own homes, hence rediscovering public spaces in their local communities that had previously lay dormant compared to the vibrant community sports 
facilities in adjacent areas. For example, children in my neighbourhood created a placed-based version of 'ultimate tag', where teams competed in an outdoors tagging-cum-Parkour competition that spread throughout their $5 \mathrm{~km}$ radius. These experiences can inform how we think about and theorise 'community' in community sport (Rich et al. 2021), and may point to a temporary resurgence of a more place-based sense of community, alongside other forms of community (e.g. virtual communities).

At the other end of the sport participation spectrum, the show must go on. Contentious politics surrounding major sporting events have gained considerable academic attention in recent years. To what extent will 'celebration capitalist' sport mega-events (Boykoff 2014) be met with increased activism and popular resistance beyond what we have already seen happening in recent years, with mega-events continuing in the face of large proportions of populations in host countries objecting to them? Will the ecological and economic toll of event hosting swell activism and mobilisation of alternative futures? What are the affective architectures that make these social movements move? Theoretically, there is still much we can glean from previous studies, such as Delaney and Eckstein's work on local growth coalitions and publicly subsidised sports stadiums (Delaney and Eckstein 2003a). Their work has also shown how academic studies have been ignored and neutralised by supporters of stadium subsidies, thereby making them less effective in policy debates (Delaney and Eckstein 2003b).

\section{Sociologists of sport as co-creators of - and actors in - social change}

My references to the important work of Delaney, Eckstein and Boykoff lead me to the question what modest contributions sociologists of sport can make not only to these debates, but to social change. How can we - as scholars - infuse these debates in ways that help to amplify impactful public sociology? I would like to spend the final part of this paper to address this very question: how might sociologists of sport serve as co-creators of, and actors in, social change?

In my own work, I have sought to advance theoretical and practical understandings of change processes in a number of ways. Teaching undergraduate and postgraduate courses is a principal means through which we can influence the dispositions and critical literacies of students, many of whom are also athletes (at any level of competition), volunteers and future administrators in sport. But our research also has transformative potential. With our team in the Sport and Social Change Living Lab at Victoria University (which I co-lead with my colleagues Fiona McLachlan, Brent McDonald and Carla Luguetti), we engage in community-based action research that aims to co-design and implement sustainable solutions to issues of inequity, discrimination and exclusion in sport, physical activity and physical education. The living lab is a collaboration between social scientists, industry professionals, community groups and volunteers working to generate cutting-edge knowledge on how to create and maintain inclusive and supportive sporting climates. Our work serves to demystify the issue of social change by focusing on micro-level change, and by making it more applied and practical, for example through our Change Makers program.

In Change Makers, a learning community of club volunteers (so-called 'change makers'), mentors, sociologists and community groups work together to co-design, implement and evaluate inclusion projects in community-based sport contexts. We train, mentor and support change makers from a wide range of sports to: (1) critically analyse their organisational climates; (2) design and implement innovative projects that address structural and cultural barriers to participation; and (3) enhance the representation of women and minorities in positions of leadership and administration. Both in Change Makers and in my other work, I seek to develop deliberate research impact pathways and co-create knowledge translation strategies and activities with partners and stakeholders. In my experience, the collaborative, participatory approach taken in much of my work has had a positive impact on the development of a shared sense of purpose and ownership, readiness for change, and the uptake of research evidence by next users and end users (e.g. Schaillée et al. 2019; spaaij and Schaillée, in press)

Finally, a word on theory. The call to action-oriented sociology of sport is not anti-theory; quite the opposite. Indeed, there is an ongoing need for theory and theory development in the sociology of sport. In this paper, I have signposted several theoretical approaches that might help to underpin our sociological analyses of key issues in sport during and beyond the Covid-19 pandemic. I acknowledge that there are other theories and concepts that can help to enlighten and strengthen such analyses, and I welcome their application. The same applies to action research towards social transformation. If we are to contribute actively and effectively to processes of social change, we need appropriate conceptual tools to ground our work in. Recent theoretical interventions in sport for 
development indicate an appetite among scholars for theoretical approaches can help explain how transformative social change might occur through sports activities (e.g. Lindsey and Wiltshire 2021; Spaaij and Schaillée 2021). In Change Makers, we bring together in a complementary way conceptual tools from a range of approaches including critical pedagogy, micro-sociology, social justice education and critical race theory. The following quote by Michael Burawoy captures the value of theory in this context remarkably well:

Theory lives not only just as a dynamic process of theorizing, but also in the lives of subjects. Communities learn to bring theory into their lives, educating themselves "with the book in hand" to the wider forces shaping their communities, problematizing the assumptions they make, and above all, making it clear that what is does not have to be (Burawoy 2017, vii).

Through this journey, I have come to see the rich creative potential that can emerge when we bring into dialogue - and treat with equal respect - sociological knowledge with the context-specific practical wisdom and professional judgement of practitioners (i.e. phronesis). This requires a recognition on the part of scholars that everyday practical knowledge is a crucial part of reflective practice, and as necessary and valuable as any other form of knowledge (Flyvbjerg 2001; Hammersley 2013); akin to Bairner's (2009) aforementioned plea for the role of organic intellectuals. And that if we are genuinely committed to contribute, however modestly, to social change, we need to create and maintain long-term coalitions and learning communities with people and organisations with lived experience and practical knowledge in the spaces we seek to transform for the better.

\section{References}

Bairner, Alan. 2009. "Sport, intellectuals and public sociology: Obstacles and opportunities."

International Review for the Sociology of Sport 44 (2-3): 115-130.

Bhattacharya, Debapriya, and Fareha R. Islam. 2020. "The COVID-19 Scourge: How affected are the Least Developed Countries?" OECD Development Matters, 23 April. Available from https://oecd-development-matters.org/2020/04/23/the-covid-19scourge-how-affected-are-the-least-developed countries/ (accessed 8 February 2021).

Bhattacharya, Debapriya, and Sarah S. Khan. 2020. "COVID-19: A game changer for the

Global South and international co-operation?" OECD Development Matters, 2 September. Avail- able from https://oecd-development-matters. org/2020/09/02/covid-19-a-game-changer-for-theglobal-south-and international-co-operation/ (accessed 8 February 2021).

Boykoff, Jules. 2014. Celebration capitalism and the Olympic games. New York: Routledge.

Brown, Adrienne M. 2019. Pleasure Activism: The Politics of Feeling Good. Chicago: AK Press.

Burawoy, Michael. 2017. "Foreword." In Achieving social impact: Sociology in the public sphere, edited by Marta Soler-Galart (pp. v-vii). Heidelberg: Springer.

Burawoy, Michael. 2005. "For public sociology." American Sociological Review 70 (1): 4-28.

Burnett, Cora. 2015. "Assessing the sociology of sport: On sport for development and peace."

International Review for the Sociology of Sport, 50(4), 385-390.

Clawson, Dan, Robert Zussman, Joya Misra, Naomi Gerstel, Randall Stokes, and Douglas L.

Anderton, eds. 2007. Public sociology: Fifteen eminent sociologists debate politics and the profession in the twenty-first century. Berkeley, CA: University of California Press.

Cohen, Joshua. 2021. "Austria locks down most of the unvaccinated, unleashing heated discussions across Europe about how to tackle the latest Covid-19 surge." Forbes, 15 November. Available from https:// www.forbes.com/sites/joshuacohen/2021/11/15/ austria-locks-down-most-of-the-unvaccinated-unleashing-heated-discussions-across-europe-about-how-to-tackle-the-latest-covid-19surge/?sh=acf4e164315e (accessed 22 November 2021).

Collins, Michael, with Tess Kay. 2014. Sport and social exclusion, $2^{\text {nd }}$ edition. London:

Routledge.

Collins, Randall. 2016. "Micro-sociology of sport: Interaction rituals of solidarity, emotional energy, and emotional domination." European Journal for Sport and Society 13 (3): 197-207.

Collins, Randall. 2011. "Interaction rituals and the new electronic media." The Sociological

Eye, 25 January. Available from http://sociological-eye.blogspot.com/2011/01/interaction-rituals-and-new-electronic.html

Collins, Randall. 2004. Interaction ritual chains. Princeton, NJ: Princeton University Press.

Cottingham, Marci. 2012. "Interaction ritual theory and sports fans: Emotion, symbols, and solidarity." Sociology of Sport Journal 29: 168-185.

Cray, Kate. 2020. "How the coronavirus is influencing children's play." The Atlantic, 2 April.

Available from https://www.theatlantic.com/ family/archive/2020/04/coronavirus-tag-and-other- 
games-kids-play-during-a-pandemic/609253/

cessed 22 November 2021).

Darnell, Simon. 2012. Sport for development and peace: A critical sociology. London:

Bloomsbury Academic. de Klerk, Josien. 2020. "Touch in the new '1.5-metre society'." Social Anthropology/

Anthropologie Sociale 28 (2): 255-257.

Delaney, Kevin, and Rick Eckstein. 2003a. Public dollars, private stadiums: The battle over building sports stadiums. New Brunswick, NJ: Rutgers University Press.

Delaney, Kevin, and Rick Eckstein. 2003b. "The devil is in the details: Neutralizing critical studies of publicly subsidized stadiums." Critical Sociology 29 (2): 189-210.

Donnelly, Peter, simon Darnell, and Bruce Kidd. 2020. The implications of COVID-19 for community sport and sport for development. Toronto: Centre for Sport Policy Studies, University of Toronto.

Elias, Norbert, and John L. Scotson. 1965. The established and the outsiders. London: Frank

Cass.

Evans, Adam, Joanna Blackwell, Paddy Dolan, Josef Fahlén, Remco Hoekman, Verena

Lenneis, Gareth McNarry, Maureen Smith, and Laura Wilcock. 2020. "Sport in the face of the COVID-19 pandemic: towards an agenda for research in the sociology of sport." 95.

European Journal for Sport and Society 17 (2): 85-

Fleming, Steve. 2020. "Lessons in survival from the sport for development sector."

sportanddev.org, 29 September. Available from https://www.sportanddev.org/en/article/news/lessons-survival-sport-development-sector (accessed on 8 February 2021).

Flyvbjerg, Bent. 2001. Making social science matter: Why social inquiry fails and how it can succeed again. Cambridge: Cambridge University Press.

Foucault, Michel. 2008. The birth of biopolitics: Lectures at the Collège de France, 1978-

1979. Basingstoke: Palgrave Macmillan.

Foucault, Michel. 1974. The archaeology of knowledge. London: Tavistock.

Fullagar, Simone. 2020. "Recovery and regeneration in community sport." Medium, 6 May.

Available from https://medium.com/the-machinery-of-government/recovery-and-regeneration-in-community-sport-9a217bd70aef

Giulianotti, Richard, Hans Hognestad, and Ramón Spaaij. 2016. "Sport for development and peace: Power, politics and patronage." Journal of Global sport Management 1 (3/4): 129-141.
Gray, Peter. 2013. Free to learn: Why unleashing the instinct of play will make our children happier, more self-reliant, and better students for life. New York: Basic Books.

Grubben, Malou, and Remco Hoekman. 2021. Sociale ongelijkheid in sportdeelname. Utrecht:

Mulier Instituut.

Hafner, Marco, Erez Yerushalmi, Clement Fays, Eliane Dufresne, and Christian Van Stolk.

2020. COVID-19 and the cost of vaccine nationalism. Cambridge: RAND Europe.

Hammersley, Martyn. 2013. The myth of research-based policy and practice. London: Sage.

Huish, Robert. 2011. Punching above its weight: Cuba's use of sport for South-South co-operation. Third World Quarterly 32 (3): 417-433.

Huizinga, Johan. 1949. Homo ludens: A study of the play-element of culture. London:

Routledge.

Jeanes, Ruth, Ramón Spaaij, Dawn Penney, and Justen O'Connor. 2019. "Managing informal sport participation: Tensions and opportunities." International Journal of Sport Policy and Politics 11 (1): 79-95.

Koopmans, Berber, and Doidge, Mark. In press. "'They play together, they laugh together':

sport, play and fun in refugee sport projects." sport in Society.

Lee, Raymond. 2010. "Weber, re-enchantment and social futures." Time \& Society 19 (2): 180-192.

Lindsey, lain, and Gareth Wiltshire. 2021. "Sport-for-development and transformative social change: The potential of Margaret Archer's morphogenetic approach to reconceptualise a longstanding problem." Sociology of Sport Journal. https://doi. org/10.1123/ssj.2020-0112

Lindsey, lain, and Alan Gratton. 2012. An "international movement"? Decentring sport-for-development within Zambian communities. International Journal of Sport Policy and Politics 4(1): 91-110.

Meade, Michael. 2020. "The power of imagination." Living Myth Podcast 175, 13 May.

Available from https://www.mosaicvoices.org/episode-175-the-power-of-imagination

Nuki, Paul, et al. 2021. "Fears of 'vaccine apartheid' as countries mull immunisation passports." The Telegraph, 18 January. Available from https://www. telegraph.co.uk/global-health/science-and-disease/ fears-vaccine-apartheid-countries-mull-immunisation-passports/ (accessed 22 November 2021).

Pape, Madeleine, and Fiona McLachlan. 2020. "Gendering the coronavirus pandemic: Toward a framework of interdependence for sport." International Journal of Sport Communication 13 (3): 391-398.

Pringle, Richard, Robert E. Rinehart and Jayne 
Caudwell. 2015. Sport and the social significance of pleasure. London: Routledge.

Rich, Kyle, Ramón Spaaij, and Laura Misener. 2021. "Theorizing community for sport management research and practice." Frontiers in Sports and Active Living 3: 774366. doi: 10.3389/fspor.2021.774366

Rowe, David. 2020. "Subjecting pandemic sport to a sociological procedure." Journal of

Sociology 56 (4): 704-713.

Sen, Kunal. 2020. "Five ways coronavirus is deepening global inequality." The Conversation,

18 August. Available from https://theconversation.com/five-ways-coronavirus-is-deepening-global-inequality-144621 (accessed 4 February 2021).

Schaillée, Hebe, Ramón Spaaij, Ruth Jeanes, and Marc Theeboom. 2019. "Knowledge translation practices, enablers, and constraints: Bridging the research-practice divide in sport management." Journal of Sport Management 33 (5): 366-378.

Spaaij, Ramón, and Hebe Schaillée. 2021. "Inside the black box: A micro-sociological analysis of sport for development." International Review for the Sociology of Sport 56 (2): 151-169.

Spaaij, Ramón, and Hebe schaillee. In press. "Collaborative evaluation in sport and leisure."

In Evaluation in Sport, Leisure and Wellbeing, edited by Kevin Harris and Andrew Adams. London: Routledge.

Spaaij, Ramón, Jonathan Magee, and Ruth Jeanes. 2014. Sport and social exclusion in global society. London: Routledge.

Spaaij, Ramón, Karen Farquharson, Jonathan Magee, Ruth Jeanes, Dean Lusher, and Sean

Gorman. 2014. "'A fair game for all? How commu- nity sports clubs in Australia deal with diversity. Journal of Sport and Social Issues 38 (4): 346-365.

Spaaij, Ramón, Sarah Oxford, and Ruth Jeanes. 2016. "Transforming communities through sport? Critical pedagogy and sport for development." Sport, Education and Society 21 (4): 570-587.

Staley, Kiera. et al. 2021. "Staying safe while staying together: the COVID-19 paradox for participants returning to community-based sport in Victoria, Australia." Australian and New Zealand Journal of Public Health. https://doi.org/10.1111/1753-6405.13177

Sterchele, Davide. 2015. "De-sportizing physical activity: From sport-for-development to play-for-development." European Journal for Sport and Society 12 (1): 97-120.

Stiglitz, Joseph. 2020. "Conquering the great divide." Finance \& Development: A Quarterly

Publication of the International Monetary Fund 57 (3): 17-19.

Tankwanchi, Akhenaten S., Brett Bowman, Michelle Garrison, Heidi Larson, and Charles S.

Wiysonge. 2021. "Vaccine hesitancy in migrant communities: a rapid review of latest evidence." Current Opinion in Immunology 71: 62-68.

Tranow, Ulf. 2020. "Digital Rituals: Can Collins' Interaction Ritual Chain Theory be applied online?" ResearchGate, 11 May. Available from https://www. researchgate.net/post/Digital_Rituals_Can_Collins_ Interaction_Ritual_Chain_Theory_be_applied_online

Webster, Christopher. In press. "The (in)significance of footballing pleasures in the lives of forced migrant men." Sport in Society.

Zirin, Dave. 2008. "Calling sports sociology off the bench." Contexts 7 (3): 28-31. 